\title{
Systemic Regulation of Global Trade and Finance: A Tale of Two Systems
}

R. Michael Gadbaw

Georgetown University Law Center, rmg57@law.georgetown.edu

Georgetown Public Law and Legal Theory Research Paper No. 11-35

Georgetown Business, Economics and Regulatory Law Research Paper No. 11-07

This paper can be downloaded free of charge from:

https://scholarship.law.georgetown.edu/facpub/624

http://ssrn.com/abstract=1785749

13 J. Int'I Econ. L. 551-574 (2010)

This open-access article is brought to you by the Georgetown Law Library. Posted with permission of the author. Follow this and additional works at: https://scholarship.law.georgetown.edu/facpub

Part of the Banking and Finance Law Commons, and the International Trade Law Commons 


\title{
SYSTEMIC REGULATION OF GLOBALTRADE AND FINANCE: A TALE OF TWO SYSTEMS
}

\author{
R. Michael Gadbaw*
}

\section{ABSTRACT}

The recent financial crisis has put enormous strains on the global systems governing international finance and trade. These two important international regulatory systems, created after World War II to promote growth and stability in the global economy, were put to the test in ways unprecedented since the 1930s. This article seeks to analyze and compare their performance as systemic regulators in the course of the crisis and concludes that the trading system performed quite well while the financial system virtually collapsed. This article seeks to account for this difference by looking at the nature of the rules and the institutions governing each and how they evolved so differently over the past 70 years. Central to the success of the World Trade Organization (WTO) is a regulatory approach that includes rules designed, and tested in practice, to align incentives with the public good and prevent regulatory capture and a self-enforcing dispute settlement mechanism that ensures accountability and enforceability. The article concludes that these differences hold important lessons for the reform of the rules and institutions governing finance and trade in the global economy, and the role the WTO should play in this reform.

\section{TRADE AND FINANCE: THE TWIN PILLARS OF SYSTEMIC} REGULATION OF THE GLOBAL ECONOMY

\section{A. Nature or nurture?}

The interplay of two global regulatory systems - finance and trade 1 deserves scrutiny in our thinking about the crisis of 2007-09 with respect

\footnotetext{
* Adjunct Professor, Georgetown University Law Center; Distinguished Senior Fellow, Institute for International Economic Law. In the interest of full disclosure, note that this article draws on the author's experience working in international economic law: in the White House (summer of 1973); in the Treasury Department and the Office of the US Trade Representative (1975-80); in private law firms (1980 to 1990) representing, among others, the semiconductor and computer industries; as Vice President and Senior Counsel of General Electric (1990 to 2008). E-mail: mgadbaw@verizon.net

${ }^{1}$ The interplay of trade and finance is as old as economic history itself. See William J. Bernstein, A Splendid Exchange; How Trade Shaped the World (New York: Atlantic Monthly Press, 2008) 18: 'First, trade is an irreducible and intrinsic human impulse, as primal as the needs for food, shelter, sexual intimacy, and companionship. Second, our urge to trade has profoundly affected
}

fournal of International Economic Law Vol. 13 No. 3 (C) Oxford University Press 2010, all rights reserved 
to what happened, the underlying causes, and how to identify and implement reforms that will mitigate or prevent crises of this magnitude in the future. Parallels to the Great Depression have been drawn as analysts, policymakers, regulators, politicians, and the general public try to develop a narrative to explain the events that reverberated across national borders to virtually every corner of the globe, utilizing the channels of globalization to spread the impact and threatening to undo many of the benefits (wealth, economic growth and asset values) to which trade and capital flows have been so instrumental. This article seeks to contribute to this dialogue by comparing and contrasting the way the global financial system and the global trading system performed as systemic regulators through the crisis. The argument will be made that the dramatic differences in the way each of these performed, with the collapse of the financial system while the trading system experienced only a minor disruption, can be attributed to important differences in their underlying regulatory systems as reflected by their respective institutions, the rules, dispute settlement and enforcement mechanisms. Ultimately, we find two profoundly contrasting regulatory paradigms for trade and finance, reflecting underlying differences in market dynamics and policies regarding the interaction of markets and rules. How did these mutually interdependent systems evolve side by side in such dramatically different directions?

The importance of this debate should not be underestimated. Although the global economy is recovering from the worst of the asset declines in housing, household wealth and financial institution solvency, the question remains whether the global economy can recover in the absence of a greater sense of confidence among investors, consumers, employers and employees that comparable crises can be avoided or at least mitigated in the future. Moreover, can the global economy function properly when the two systems of trade and finance seem so out of synch in terms of the quality of their regulatory frameworks and the strains that must be absorbed by one when the other fails to carry its weight in maintaining the stability of the overall system.

\section{B. Systemic performance-finance and trade-crisis to crisis}

The totality of the collapse in our global economy, attributed in part to economic policies and regulatory failures, has led us to take a system wide view of causes and effects. Systemic failure and its counterparty systemic risk have entered our public policy lexicon. This kind of top down preoccupation has its historical parallels. The Great Depression prompted a rethink of our economic policies and the adoption of Keynesian intervention to promote

the trajectory of the human species.' See also Niall Ferguson, The Ascent of Money: A Financial History of the World (New York: The Penguin Press, 2008) 2: 'Despite our deeply rooted prejudices against "filthy lucre", however, money is the root of most progress.' 
full employment and economic growth. Internationally, Lord Keynes and his colleagues seized the opportunity in the aftermath of the World War II to create the Bretton Woods triumvirate, comprising the International Monetary Fund (IMF), the World Bank, and the General Agreement on Tariffs and Trade (GATT), to bring countries together in a comprehensive set of international institutions based on the rule of law and the principles of free trade and economic integration. ${ }^{2}$ The series of financial crises over the ensuing decades - starting with the US decision to abandon the gold standard in the early $1970 \mathrm{~s},{ }^{3}$ followed by the Russian and Latin American crises of the 1990s, and the Asian crisis of 1998 - actually reinforced the view that the system, as it had evolved at those times, was sound and could be managed, by the likes of the Committee to Save the World, ${ }^{4}$ to handle the occasional crisis.

Now we find ourselves thinking once again about systemic failure, systemic risk and systemic regulation. Systemic risk is generally used only in connection with financial regulation to refer to 'a problem with payment or settlement systems or...some type of financial failure that induces a macroeconomic crisis'. ${ }^{5}$ For reasons explained more fully below, the concept is used here more broadly to encompass a failure of any major pillar of our global economy, including trade and finance, which leads to a macroeconomic crisis. Including the trading system as a source of systemic risk is consistent with our historical experience in the 1930s when protectionism was an important factor in the cause, depth, and length of the Great Depression. Moreover, this perspective allows us to consider the policies and institutions that have led us, perhaps too easily, to take for granted the notion that trade cannot be a source of macroeconomic failure.

In the 1930s, what started as a financial crisis with a run on the banks, also turned into a full-blown economic crisis and more than a decade of depressed economic growth, notwithstanding a complete shift in the paradigm for government intervention from laissez faire to Keynesian

${ }^{2}$ For an excellent review of the origins of Bretton Woods and the challenges facing the system in the aftermath of the financial crisis, see Richard N. Gardner, 'The Bretton Woods-GATT System after Sixty-five Years: A Balance Sheet of Success and Failure', 47 Columbia Journal of Transnational Law 26 (2008), at 27; see also the paper by Andreas Lowenfeld in this issue at $575-595$.

${ }^{3}$ One of the key linkages between trade and finance has been the use of trade measures for balance of payments reasons, the most significant case of which was the $10 \%$ import surcharge imposed by President Nixon in 1971. See John H. Jackson, William J. Davey and Alan O. Sikes, Jr., Legal Problems of International Economic Relations (5th edn St. Paul, MN: Thomson West, 2008) 1098-109.

${ }^{4}$ This reference comes from the cover of Time, 15 February 1999, http://www.time.com/time/ covers/0,16641,19990215,00.html (visited 3 August 2010) which featured Robert Rubin, Lawrence Summers and Alan Greenspan for their work in the aftermath of the Asian financial crisis.

${ }^{5}$ Kern Alexander, Rahul Dhumale and John Eatwell, Global Governance of Financial Systems; the International Regulation of Systemic Risk, (Oxford: Oxford University Press, 2006) 24. 
intervention. The critical point for our purposes is the way the trading system performed as a result of the passage in 1930 of the Smoot-Hawley Tariff Act, ${ }^{6}$ which erected insurmountable tariff barriers on goods coming into the USA and reduced both the value and the volume of international trade with the USA by as much as $50 \%$. Not only did this intervention account for a very high percentage in the decline in trade, as distinct from the fall in demand, but this intervention was mimicked by other countries that erected similar barriers around the globe, the cumulative result of which was to exacerbate the depression and block a critical avenue for post-crisis recovery.

The contrast with the crisis of 2007-09 is striking. While there was a decline of around $18 \%$ in the peak-to-trough value of international trade in the first year of the crisis, that decline was virtually entirely the result of a decline in demand, not of government intervention. ${ }^{7}$ Under the scrutiny of global institutions and private trackers, the government interventions were of minor consequence; less than $1 \%$ of global trade by some accounts. ${ }^{8}$ In the second year after the crisis (2011), global trade is expected to grow at a rate of over $9 \%$; and for many countries, not least the USA, international trade is seen as one of the critical channels for economic recovery. ${ }^{9}$

In contrast to the trading system, which performed well throughout the crisis, the financial system seems to have failed in fundamental ways across the spectrum of monetary policy and prudential supervision. ${ }^{10}$

${ }^{6}$ United States: Tariff Act of 1930, Act of June 17, 1930, 46 Stat. 685.

${ }^{7}$ The performance of the WTO in the course of the crisis has been ably analyzed in Brendan Ruddy, 'The Critical Success of the WTO: Trade Policies of the Current Economic Crisis', 13(2) Journal of International Economic Law 287 (2010) 475-95. Ruddy looks at the economic literature and the tracking systems that document and measure the effect of protectionist measures and concludes: 'unlike the trade restrictive measures of the Great Depression, measures taken during the current economic crisis have not materially contributed to the decline in trade volume and GDP'. This conclusion is also supported by the WTO's own analysis.

${ }^{8}$ Ibid, fn 48 and accompanying text.

${ }^{9}$ For a very thorough analysis of the failure of protectionism to manifest in the course of the recent crisis, with a very low-key endorsement of the WTO's role, see Simon J. Evenett, Bernard M. Hoekman and Olivier Cattaneo (eds), Effective Crisis Response and Openness: Implications for the Trading System (Washington, DC: World Bank and Center for Economic and Policy Research, 2009), at 5. The countries that were most protectionist in their responses were not members of the WTO (Algeria and Russia) (p. 5).

${ }^{10}$ To assist the reader, the primary sources for this description of the crisis are collected here. For a first hand account of the collapse of Lehman Brothers and the ensuing collapse of the financial markets, see Andrew Ross Sorkin, Too Big to Fail (New York: Viking, 2009). Michael Lewis has looked at the small group of hedge fund managers who saw the coming crisis and took advantage of it by betting against it in Michael Lewis, The Big Short: Inside the Doomsday Machine (London: Allen Lane, 2009). Nassim Nicholas Taleb has looked at the role of financial models for valuing assets and risks and how these models miscalculated the probability of events with catastrophic consequences in Nassim Nicholas Taleb, The Black Swan: The Impact of the Highly Improbable (New York: Random House, 2007). Richard A. Posner documents his own conversion from a Chicago school critic of excessive financial regulation to a more pragmatic advocate for the proper balance of regulations and the market in a capitalist 
There is a growing consensus that regulators individually-and the regulatory system as a whole-should have anticipated some of the consequences of the behavior of the market and market participants and responded to counter those effects before they led to the collapse of the financial system. ${ }^{11}$ It is this systemic character of the collapse that lends the most credence to the conclusion that the regulators failed, because it appears that quite a number of factors had to work together to create an overall system-wide failure. What began as an asset bubble in the housing market ${ }^{12}$ was fed by the availability of easy money (caused in part by global imbalances involving high saving countries like China and India exporting capital to low savings countries like the USA and UK) and was exacerbated by the ability of banks to securitize mortgages and move risk from their balance sheets to the broader markets, which in turn responded

system, first in Richard A. Posner, A Failure of Capitalism: The Crisis of '08 and the descent into Depression (Cambridge, MA: Harvard University Press, 2009) and Richard A. Posner, The Crisis of Capitalist Democracy (Cambridge, MA: Harvard University Press, 2010). Simon Johnson has analyzed the concentration of the banking industry and the role of campaign contributions in shaping the regulatory framework for finance in Simon Johnson, 13 Bankers: The Wall Street Takeover and the Next Financial Meltdown (New York: Pantheon Books, 2010).

${ }^{11}$ Some of the major regulatory failings cited as causes of the crisis: the failure of the monetary system to deal with global imbalances which facilitated the lax monetary policy of the Federal Reserve and the unwillingness to recognize the systemic risk of excessive credit leading to excessive risk taking; the role of Fannie Mae and Freddie Mac in subsidizing home ownership and the role of their implicit government guarantee in excessive risk taking, the role of the Community Reinvestment Act of 1977 (Codified to 12 U.S.C. 2901 note; Section 801 et seq. of title VIII of the Act of October 12, 1977, Pub. L. No. 95-128; 91 Stat. 1147, effective October 12, 1977) in requiring federal regulatory agencies to encourage banks to take on excessive risks in subprime mortgages; the Securities and Exchange Commission's (SEC) decision to loosen the leverage requirements on investment banks, failure of the SEC to identify the burgeoning fraud in regulated financial institutions; the repeal of the Glass-Steagell Act (The Banking Act of 1933, 48 Stat. 162) restrictions on the separation of investment and commercial banking, the authorization in Gramm-Leach-Bliley Act (The Financial Services Modernization Act of 1999, 113 Stat. 1338, Public Law 106-102) for financial holding companies to enter into a wide array of activities including banking insurance and securities while still enjoying federal deposit insurance; the failure to regulate over the counter derivatives later confirmed by legislation, the failure to see flaws in the AAA ratings that the rating agencies were giving to securitized mortgages, the failure of the Fed to regulate predatory lending of non-bank financial institutions, the failure to see how AAA-rated, mortgage-backed securities would undermine bank balance sheets, the failure to see the inadequacy of the risk assessment models of financial institutions and the failure to regulate the size of financial institutions leading to the too-big-to-fail problem. See generally Howard Davies and David Green, Global Financial Regulation: The Essential Guide (Cambridge: Polity Press, 2008); James Barth, Gerard Caprio, Jr. and Ross Levine, Rethinking Bank Regulation: Till Angels Govern (New York: Cambridge University Press, 2006) which presents a comparative study of bank regulation across 150 countries; Viral V. Acharya and Matthew Richardson, Restoring Financial Stability: How to Repair a Failed System (New Jersey: John Wiley \& Sons, 2009).

${ }^{12}$ In California, in 2007, over $90 \%$ of the securitized mortgages were so-called thin file mortgages, that is, there was no verification of the income of the borrower; most of the mortgages insured by Freddie and Fannie were subprime mortgages since only $12 \%$ of the Californian population could afford a median priced home (See Howard Savage, Current Housing Reports: 'Who Could Afford to Buy a Home in 2004', US Census Bureau, Issued May 9, 2009). 
by creating insurance policies against the failure of these mortgage-backed securities and the institutions that held them. The volume of insurance policies on mortgage-backed securities, allowing investors to bet for and against their failure, by far exceeded the amount of underlying mortgages. The appetite for these mortgage-backed securities and their related insurance policies spread across the global financial system. Because many of these securities were rated AAA by the credit-rating agencies, some institutions could originate the instruments and sell them for a handsome fee while others could buy them as part of their underlying capital structure, allowing them to leverage themselves further to do more and more lending.

What regulators and market participants missed were the inherent risks of this interaction, which in hindsight have become all too clear. When housing prices started to decline, institutions at the center of the mortgage origination and securitization process started to fail. These failures tipped the balance in the market, undermining the value of mortgage-backed securities and in turn the institutions that held them. Because the mortgages were so much a part of the capital structure of many financial institutions, what started as a liquidity crisis quickly turned into a solvency crisis, which very quickly implicated institutions so interconnected that their failure (or impending failure) brought to a halt the entire system by which financial institutions perform their functions of clearing payments, intermediating investment, and allocating risk and capital. Compounding all of these market interactions are allegations of lack of transparency, fraud and misrepresentation at both the transactional and institutional level, together with complicity on the part of regulators who were mandated to oversee risk management, consumer protection, institutional integrity, and the proper functioning of markets.

At the end of the day, the numbers tell a story but cannot capture the full impact. In the USA alone, $\$ 11$ trillion in household wealth and 8 million jobs were lost as the economy hit an annualized rate of decline in gross domestic product (GDP) of $6.2 \%$ in the fourth quarter of $2008 .^{13}$

The contrast in the performance of the global trade and financial systems in the course of the recent crisis leads to an important conclusion for policymakers: while systemic failure was the chief characteristic of the global financial system, the trading system, judged on its face solely by its performance in the course of this crisis, has emerged as a candidate for the most successful systemic regulator in the history of humankind. ${ }^{14}$ The next section of this article analyzes this characterization by comparing the regulatory

13 Catherine Rampell, 'GDP Revision Suggests a Long, Steep Downfall', New York Times, 27 February 2009, http://www.nytimes.com/2009/02/28/business/economy/28econ.html (visited 10 September 2010).

${ }^{14}$ See R. Michael Gadbaw, 'The WTO as a Systemic Regulator?', The Globalist, 16 February 2010, http://www.theglobalist.com/storyid.aspx?StoryId=8214 (visited 3 August 2010). 
systems governing trade and finance in an attempt to identify those aspects of the two systems that seem to play the most important roles in protecting against systemic risk.

\section{CHARACTERISTICS OF THE TRADE AND FINANCIAL SYSTEMS:}

\section{BRETTON WOODS REVISITED}

\section{A. From a common origin to different paths}

In the course of the recent crisis, trade did not exacerbate the crisis by translating the shock of the stock market crash into a contagion fed by chain reactions throughout the global economy. Instead, countries heeded the call in the G-20 statement of November 2008 that all economies refrain from protectionist interventions in their markets. ${ }^{15}$ Meanwhile, the capital markets ground to a halt as the credit markets froze when banks and other financial institutions were unwilling to lend to all but the most creditworthy borrowers. This leads to the questions: Why do these regulatory systems look so different? How did they evolve in such different directions? What were the aspects of the trading system that helped protect it from systemic failure? How do these characteristics compare to the financial system?

In considering this question, it is helpful to remind ourselves what a 'political miracle ${ }^{, 16}$ the Bretton Woods system was. ${ }^{17}$ The American Bankers Association claimed that the IMF would amount to 'handing over to an international body the power to determine the destination, time, and use of our money...abandoning, without receiving anything in return, a vital part of American bargaining power'. ${ }^{18}$ The National Foreign Trade Council, the National Association of Manufacturers and the US Chamber of Commerce were staunchly opposed to the proposed International Trade Organization (ITO) and helped to kill it in the US Congress. In the end, the vision of the founding fathers prevailed:

They conceived of a postwar economic system ruled by law. They wanted it to be a universal system... rather than a collection of trading blocs.

${ }^{15}$ Paragraph 48 of the Pittsburgh Summit Communique, September 25, 2009.

${ }^{16}$ See Gardner, above n 2, at 28-32. Gardner points out the changes to the world order that have occurred since 1948, particularly:

the 'money bags', the 'brains', the economic weight and the political influence are all more evenly distributed today than they were.... Yet the old and difficult issues that confronted the founding fathers of the Bretton-Woods system are still with us- how to reconcile freedom of international trade and payments with full employment and social justice at home, how to balance the need for effective international economic institutions with still-powerful demands for national economic sovereignty, and how to relate regional and bilateral economic arrangements to a global economic order.

${ }^{17}$ Powerful political and intellectual currents on both sides of the Atlantic opposed the creation of these institutions. Ibid, at 28.

${ }^{18}$ Ibid, at 31 . 
They wanted permanent international institutions to promote cooperation on monetary, trade, and development problems. And they wanted somehow to reconcile the concept of maximum possible freedom in trade and payments at the international level with the domestic pursuit by governments of progressive economic and social policies. ${ }^{19}$

'Monetary questions had to be dealt with before trade questions... because countries would not be willing to commit themselves to tariff reductions if the conditions of competition could be completely altered by large and unforeseen changes in exchange rates. ${ }^{20} \mathrm{~A}$ fixed exchange rate system based on gold and special drawing rights was adopted when the Keynes proposal for a Clearing Union with global overdraft facilities proved too ambitious and the founders anticipated that there would be a high degree of voluntary coordination of economic policy. From a systemic perspective, the critical issue that the Bretton Woods founders faced was how to reconcile an open international trading system with the free movement of capital. In the end, the importance of open trade took preeminence over capital movements. Finally, there was a fight over whether to authorize, encourage or prohibit capital controls that ultimately led to a compromise in which capital controls were allowed, even encouraged, but countries were not required to cooperate in their application.

For our purposes, the fight over capital controls was the most important because it pitted the New York bankers against the founders in a fight that led to the triumph of finance ministries over the New York bankers and their central bank allies ${ }^{21}$ and prompted Henry Morgenthau to proclaim that one of the goals of Bretton Woods was to 'drive the usurious moneylenders from the temple of international finance'. ${ }^{22}$ In this respect, the founders backed away from a total commitment to an open, liberal international economic order and, instead, institutionalized the view that 'a liberal financial order would not be compatible, at least in the short run, with a stable system of exchange rates and a liberal trading order'. ${ }^{23}$ Underlying this position were complementary economic and strategic views. On the economic side, 'capital controls were necessary to prevent the policy autonomy of the new interventionist welfare state from being undermined by speculative and disequilibrating international capital flows'. ${ }^{24}$ On the strategic side, the US foreign policy establishment believed that a benevolent attitude toward the interventionist

\footnotetext{
${ }^{19}$ Ibid, at 32 .

${ }^{20}$ Ibid, at 36

${ }^{21}$ Eric Helleiner, States and the Reemergence of Global Finance; From Bretton Woods to the 1990s (Ithaca and London: Cornell University Press, 1994) 45.

22 Cited in Gardner, above n 2, at 38.

${ }^{23}$ Ibid, at 5 .

${ }^{24}$ Ibid, at 4 .
} 
policies of Europe and Japan was the most effective means of promoting economic growth and sustaining the Cold War alliance. ${ }^{25}$

Ironically, the importance of international trade to the policymakers ran headlong into political reality. When the over ambitious ITO project was unable to overcome political opposition, the GATT was forced to survive on life support through most of its early years. Compared to its sister organizations, the IMF and the World Bank-which were busy through the decades of 1950s and 1960s building up a sizable staff, planting a dramatic bricks-and-mortar physical footprint in Washington, DC and spending their considerable resources - the GATT, or more accurately, the Interim Commission for an ITO, had to struggle in political obscurity until 1968 when the US Congress took the modest step of providing permanent authorization for contributions to the GATT Secretariat. ${ }^{26}$ The GATT took on the challenge of proving itself as an effective international regulatory framework. Aided by the US willingness to lead with open markets and Marshall Plan assistance and some exceptional leadership within the organization from individuals like Eric Wyndham White, the GATT ultimately concluded eight major rounds of trade negotiations. 'Pragmatic accommodation, good practical sense, and important leadership led a weak "birth defected" GATT to become an important part of the world's international economic institutional landscape. ${ }^{27}$

Europe was the critical partner throughout this period. European support for the GATT was affirmed politically and economically as the European Communities transposed the basic framework of the GATT into the core principles for their economic union and the very identity of Europeans became associated with economic integration through the elimination of internal barriers to trade among European countries and eventually the single European market.

The 1970s proved to be a watershed decade for both the trade and the international financial system. By the end of the decade, the USA had abandoned the dollar's link to gold, imposed an import surcharge on Japan to force currency realignment, and launched the modern era of flexible exchange rates. Treasury officials decided to reverse their benevolent attitude toward capital controls and began to adopt policies encouraging the flow of capital, teaming up with the banks to use commercial leverage to affect the economic policies of other countries. ${ }^{28}$ Meanwhile, the GATT concluded the Tokyo Round. It was the most ambitious trade negotiation round in history with agreements to lower tariffs, codes on such nontariff barriers as

25 Ibid, at 5 .

${ }^{26}$ See Gardner, above $\mathrm{n} 2$, at $50-51$.

${ }^{27}$ John H. Jackson, Sovereignty, the WTO, and Changing Fundamentals of International Law (New York: Cambridge University Press, 2006) 261.

${ }^{28}$ Helleiner, above n 21, 112-115. 
subsidies, government procurement, valuation and standards, and the elimination of some sacred cows (e.g. the American Selling Price system, Wine-Gallon Proof-Gallon valuation of imported spirits) that had been grandfathered in the GATT and were a longstanding source of tension with US trading partners. Approval of this liberalizing package by an overwhelming vote in Congress, even in the face of a recession, was made possible by a US fast-track legislative approval scheme that was nothing short of a revolution in the political economy of trade. ${ }^{29}$ In short, the table was set for the globalization of the global economy driven by trade and capital movements that would be the dominant economic story of the following three decades.

Also important in the 1970s was the emergence of an alliance of right and left around the theme of regulatory efficiency. Contrary to the views of some that this was principally a conservative phenomenon, Eduardo Canedo has argued that the movement that became associated with deregulation had its roots in the convergence of views from the Chicago School of Economics (on the right), under the intellectual leadership of George Stigler, and from the left, under the intellectual and political instigation of Ralph Nader. ${ }^{30}$ Both Stigler and Nader were highly skeptical of the role of government regulation, Stigler out of an innate faith in the market, Nader from the perspective that regulatory agencies were more likely to be captured by those they were intended to regulate. While these movements diverged over the issue of social regulation, they were extremely influential in the initiatives to deregulate a number of areas, from aviation and trucking to natural gas and power generation.

${ }^{29}$ For a detailed account of the political history of trade politics, see I. M. Destler, American Trade Politics, 4th ed. (Washington, DC: Institute for International Economics, 2005).

${ }^{30}$ See Eduardo Canedo, 'The Rise of the Deregulation Movement in Modern America 1957-1980' (2009 PhD dissertation on file at Columbia University, Department of History), at 97 (cited with the permission of the author). See also Joshua Green, 'Inside Man', The Atlantic Monthly, April 2010 (http://www.theatlantic.com/magazine/archive/2010/ 04/inside-man/7992/) and a description of the defections from the Chicago School in John Cassidy, 'After the Blowup; Laissez-Faire Economists Do Some Soul-Searching - and Finger-Pointing', The New Yorker, 11 January 2010, 28. John Cassidy recounts a history lesson from Richard A. Posner, a jurist and intellectual leader of the Chicago School:

By the late 1980s, with the collapse of Communism, the basic insights of the Chicago School about deregulation and incentives had been accepted worldwide, he recalled, and the bitter enmity between Chicago and its rival economics departments had faded. Eventually, many of the founders of the Chicago School died, and were replaced by more moderate figures, such as Thaler and Levitt. Now, largely as a result of misguided efforts to extend deregulation to the finance industry, we have experienced the biggest economic blowup since the nineteen-thirties. Posner, who appeared to be enjoying his role as a heretic, paused, then said, 'So probably the term "Chicago School" should be retired'.

Available at: http://mfs.uchicago.edu/pastworkshops/capitalisms/readings/After_the_Blowup. pdf (visited 3 August 2010). 
It was the resurgence of US competitiveness in the 1980s and the confidence that it gave to Americans that helped support the extreme monetary policies that Paul Volcker introduced in the early 1980s to break the grip of inflation on the US economy. The success of this policy in turn helped form the basis for the Washington Consensus, namely that the key to international development lay in the adoption of carefully managed monetary policies, open trade policies and liberalizing financial markets. The strong US economy buttressed the role of the US dollar and overwhelmed any efforts to replace it with the special drawing right or other currencies. It also gave US Treasury officials few incentives to consider new rules for global finance. New rules for the global world of finance were unnecessary because domestic policymakers could oversee the system, and all that was needed were loose confederations of regulators whose objective would be the exchange of ideas on collective problem solving.

It is said that nothing succeeds like success, and this unfettered model of regulation marked an era of unprecedented growth in the financial sector and the proliferation of financial instruments. While global trade grew steadily over the past 50 years, exceeding GDP growth rates and reaching $\$ 14$ trillion by 2007, financial assets saw explosive growth from being about equal to global GDP in 1980 to over three times GDP by the end of 2005. By 2007, financial services accounted for over one third of corporate profits in the USA and an estimated 5.9\% of US GDP, up from 3.5\% of GDP in 1978 depending on how you calculate it. ${ }^{31}$ This explosion in the markets for financial services was accompanied by the globalization of those markets and the combination of size, complexity, growth and global scope beyond the grasp, if not the reach, of national regulators set the stage for what some predicted would be a systemic crisis of global proportions. ${ }^{32}$

Somewhat ironically, the financial community was one of the most ardent supporters of the emerging rules of the international trading system, even as they resisted regulation as it would be applied to finance. Moreover, financial interests, through their associations, sought new rules in the context of the international trading system but their focus was on limiting restrictions that countries could use to constrain the operations of financial institutions across borders. These new rules were developed in what eventually became known as the General Agreement on Trade in Services (GATS), incorporated with

31 Johnson, n 10, at 60-61.

32 See Alexander et al., above n 5, at 7: 'The recent history of capital market liberalization has coincided with a swing in the balance of intellectual influence from a postwar theory of economic policy that urged national governments to limit international capital movements to the present-day theory that encourages free capital movements and the abdication of national regulatory powers. So financial stability is largely a matter of convention.' Written in 2006, these authors make one of the most compelling predictions at page 9: 'Recent crises suggest the current international efforts to regulate financial systems lack coherence and legitimacy and fail to effectively manage systemic risk.' 
the World Trade Organization (WTO) in 1995, and subject to further negotiations in the Doha Round. ${ }^{33}$

Meanwhile, as predicted, the floating exchange rate system did lead to crises, but these were successfully managed on an ad hoc basis with governmental and IMF bailouts that were seen as confirmation of the importance of implementing more rigorously the Washington Consensus, particularly in emerging markets. The importance of crisis management in preparing individuals and their mindset for the latest crisis is well described by Joshua Green in his profile of Timothy Geithner:

Geithner came of age in Washington just after the Cold War ended, when the country's preoccupation with wealth and the long bull market made Treasury a nerve center of the government. It helps explain Geithner to think of him as someone whose formative experience was in figuring out how to contain the series of upheavals that swept the international financial community in the 1990s, from Japan to Mexico to Thailand to Indonesia to Russia, and threatened the boom. Toward the end of the Clinton administration, a view emerged that the government had more or less figured out how to manage the global financial system. Those at the helm won extraordinary renown. The era's time-capsule-worthy artifact is a Time cover touting Alan Greenspan, the Federal Reserve chairman, Robert Rubin, the Treasury secretary, and Lawrence Summers, Rubin's deputy, as 'The Committee to Save the World'. Geithner was an aide de camp. ${ }^{34}$

It was roughly during this same period from 1980 to 1995 when the trading system made its most extraordinary evolution into a global systemic regulatory system. The great debate-whether the GATT should be a rule-based system with a juridical function or an essentially diplomatic facilitator where trade issues could be resolved through negotiations-was resolved in favor of converting soft law into hard law or hard-hard law. It is nothing short of revolutionary that the Uruguay Round was concluded with a single undertaking that every country in the world was required to take or leave and a dispute settlement understanding that gave any country the right to challenge the practices of any other country, no matter how big or small. Whether this system would work or not was unclear but the history

33 The Financial Service portion of the GATS deals narrowly with measures that limit the cross border establishment and operation of financial institutions but the obligations are implemented not on a generalized basis but country by country and measure by measure, depending on the willingness of countries to incorporate the obligation into their schedule. The prudential exception [General Agreement on Trade in Services, Annex on Financial Services, para. 2(a)] could be a framework for incorporating rules on prudential supervision and this exception is subject to WTO dispute settlement, however, there has been little interest in this possibility to date. For the most part, countries have simply incorporated into their schedules their existing framework of regulations.

${ }^{34}$ Joshua Green, 'Inside Man', The Atlantic Monthly, April 2010, http://www.theatlantic .com/magazine/archive/2010/03/inside-man/7992/ (visited 3 August 2010). 
since then is clear; the enforcement record of the institution is singular and the stress test of the Great Contraction has confirmed at least to date that the system is still holding. ${ }^{35}$

By the dawn of 2007, these two systems that started life from a common conception had evolved two very different regulatory and institutional structures. The WTO became a member-driven, rule-oriented, unitary, comprehensive and nearly universal system where the obligations run horizontally from members to other members, decisions are made by consensus, and obligations are interpreted and enforced through a dispute settlement mechanism with a highly developed juridical function having the power to determine violations and authorize sanctions. The international financial regulatory system became a fragmented, complex, multi-tiered, multi-dimensional, resource-oriented system ${ }^{36}$ that accommodates the different domains and regulatory prerogatives of finance officials, central bankers, and bank regulators as well as the private financial community by creating a variety of different organizations from treaty-based to intergovernmental to cooperative arrangements among functional regulators.

\section{B. Contrasting regulatory philosophies}

The philosophical principles underlying the global trading system will be explored in some detail in the next section, so it is sufficient here to set up in contrast some of the core thinking around the financial system through the views of two of the major operational and intellectual leaders (Alan Greenspan and Robert Rubin) reflecting on why they did not anticipate the crisis.

It is helpful to start with the October 2008 testimony of Alan Greenspan, former Chairman of the Federal Reserve, which posed the question: 'What

\footnotetext{
${ }^{35}$ See WTO Appellate Body, 'Annual Report for 2009', WT/AB/13, 17 February 2010.

${ }^{36}$ There is an interesting view that the IMF started as a rule-based system while the GATT started on a more flexible, 'ideas-based' system but they reversed their characters over time. See Barry Eichengreen and Peter B. Kenen, 'Managing the World Economy under the Bretton Woods System: An Overview' in Peter B. Kenen (ed), Managing the World Economy: Fifty Years After Bretton Woods (Washington, DC: Institute for International Economics, 1994) 3-57, at 7:

The International Monetary Fund was a formal structure intended to enforce an explicit set of rules; its Articles of Agreement contained a detailed list of international monetary do's and don'ts and established enforcement capabilities. Some of the rules were not enforceable, however, and they failed to anticipate all the subsequent problems. The [GATT], by contrast, was an ad hoc agreement intended mainly to provide a framework for pursuing nondiscriminatory, multilateral trade liberalization. Many observers would now conclude that the GATT was the more effective arrangement. The strength of a formal arrangement such as the IMF is its rigidity; that of an informal, ideas-based institution such as the GATT is its adaptability. The greater success of the GATT thus illustrates the importance for post-war economic performance of an adaptable institutional framework.
} 
went wrong with global economic policies that had worked so effectively for nearly four decades? ${ }^{37} \mathrm{He}$ goes on to focus on the failure of the market in subprime mortgages:

subprime mortgages pooled and sold as securities became subject to explosive demand from investors around the world. These mortgage backed securities being 'subprime' were originally offered at what appeared to be exceptionally high risk-adjusted market interest rates. But with US home prices still rising, delinquency and foreclosure rates were deceptively modest. Losses were minimal. By the most sophisticated investors in the world, they were wrongly viewed as a 'steal'. ${ }^{38}$

In an exchange with Henry Waxman, Chairman of the House Oversight Committee and Government Reform, former Chairman Greenspan is asked about the responsibility of regulators: 'You had the authority to prevent irresponsible lending practices that led to the subprime crisis. You were advised to do so by many others.... Do you feel that your ideology pushed you to make decisions that you wish you had not made? ${ }^{39}$

In response, Chairman Greenspan concedes: 'Yes, I've found a flaw. I don't know how significant or permanent it is. But I've been very distressed by that fact.' In explaining his excessive faith in the self-correcting power of free markets and his failure to anticipate the collapse of the mortgage lending system, he states: 'Those of us who looked to the self-interest of lending institutions to protect shareholders' equity, myself included, are in a state of shocked disbelief. ${ }^{40}$ Finally, in his prepared comments, he made reference to the power of regulation relative to the impact of market discipline: 'Whatever regulatory changes are made, they will pale in comparison to the change already evident in today's markets.... Those markets for an indefinite

${ }^{37}$ Alan Greenspan, Prepared testimony to the House Committee on Oversight and Reform, 23 October 2008. http://oversight.house.gov/index.php?option=com_content\&view=article\&id= $3470 \&$ catid $=42$ : hearings\&Itemid $=2$ (visited 6 October 2010).

${ }^{38}$ Ibid. http://oversight.house.gov/index.php?option=com_content\&view=article\&id $=3470 \&$ catid $=42$ :hearings $\&$ Itemid $=2$ (visited 6 October 2010).

${ }^{39}$ Ibid. In his prepared testimony, Greenspan concentrates on the market for securitized subprime loans:

It was the failure to properly price such assets that precipitated the crisis.... The modern risk management paradigm held sway for decades. The whole intellectual edifice, however, collapsed in the summer of last year [2007] because the data inputted into the risk management models generally covered only the past two decades, a period of euphoria. Had instead the models been fitted more appropriately to historic periods of stress, capital requirements would have been much higher and the financial world would be in far better shape today, in my judgment. http://oversight. house.gov/index.php?option $=$ com_content\&view $=$ article\&id $=3470 \&$ catid $=$ 42:hearings\&Itemid=2 (visited 6 October 2010).

${ }^{40}$ See Edmund L. Andrews, 'Greenspan Concedes Errors on Regulation', New York Times, 23 October 2008, http://www.nytimes.com/2008/10/24/business/economy/24panel.html (visited 30 September 2010). 
future will be far more restrained than would any currently contemplated new regulatory regime. ${ }^{41}$

This picture is filled out further by the testimony of Robert Rubin, Chairman of the Board of Citibank, to the Financial Crisis Investigatory Commission in questioning by Douglas Joltz-Eakin:

Mr. Rubin, you said no one could have foreseen this crisis and that was a universally held belief... The question is...could you have foreseen the spark that lit the crisis,... the poor standards in underwriting, the poor assessment of risks associated with mortgages, the inadequate hedging and capital provisions...? ?... In your experience, we have seen crises in Mexico, in Thailand and in the Far East, wouldn't there be grounds to be suspicious at some point? ${ }^{42}$

Rubin responds:

It's a good question....I didn't say no one could have foreseen [the crisis], some people did foresee. What I said was that very few people foresaw the full combination.... You had a large combination of forces that came together....I think it was this extraordinary combination of many factors that came together and you can say well you can see some of these and why didn't that suggest that this could be a problem....I actually did worry about the excesses and talked about them in speeches in 2005 and $2006 \ldots$. What I didn't see, and virtually nobody saw, was that it wasn't only those excesses but it was so many other factors coming together at that time and I think it's that combination that led to this crisis....As long as we have had capital markets, we have had crises and then when you look back...you say those were some obvious warning signs but they weren't obvious at the time. They were only obvious in hindsight. I personally think unfortunately that market-based systems which I believe in strongly, will have periodic down cycles and that is why this financial reform effort is so extremely important. ${ }^{43}$

\section{Characteristics of the robust regulatory system governing trade}

While systemic risk is typically associated with financial systems and crises, it seems to be applicable to the trading system and, indeed, provides a perspective from which all regulatory systems should be evaluated. As we saw in the case of the Great Depression, the trading system failed in a systemic way, that is, a shock resulted in reactions in one country that then triggered a chain reaction throughout the global economy causing a breakdown in the

41 Ibid.

${ }^{42}$ See $\mathrm{n} 43$ below.

${ }^{43}$ Robert Rubin Testimony to the Financial Crisis Investigative Commission, 8 April 2010, transcribed from the audio available at http://www.cspan.org/Watch/Media/2010/04/08/HP/ R/31560/Govt+officials+testifying+Frmr+Citi+execs+apologize.aspx (visited 3 August 2010). 
entire framework for international trade. This pattern did not repeat itself some 80 years later when the global economy went through a very similar experience to that in 1929, namely a banking crisis that put enormous pressure on governments to mitigate the impact of the crisis in their individual markets by erecting barriers to international trade. While the G-20 governments called on one another ${ }^{44}$ to refrain from such measures, it does not seem that this hortatory call explains the fact that governments responded very differently this time around, any more than hortatory calls for countries to maintain the safety and soundness of their financial institutions preserved the financial system from systemic failure. What then explains this difference?

Let's start with Paul Blustein who, judging by the title of his recent book, has quite a different view of the state of the international trading system: Misadventures of the Most Favored Nations; Clashing egos, Inflated Ambitions and the Great Shambles of the World Trade System. Blustein takes a somewhat more measured view in the book itself: 'The trading system is at risk of joining the financial system in crisis. That is the central message of this book, and the story of how the system reached this parlous state will unfold in chapters to come. ${ }^{45}$ Blustein provides an insightful and readable account of the difficulty trading nations have had concluding the Doha Round of trade negotiation and in doing so points out the most fundamental weakness of the international trading system, namely that the rule making or legislative side of the system is not nearly as developed as the juridical and rule enforcement side. ${ }^{46}$ One can juxtapose this view with the one widely held among finance experts commenting on the WTO, that the system is simply not enforcing its rules:

The WTO operates without any international enforcement powers and relies on consensus among all member nations to establish policies consistent with the agreed rules. Lack of enforcement often makes compliance problematic, and agreements to reduce trade barriers can only be reached after endless rounds of negotiation such as the currently ongoing Doha

${ }^{44}$ Paragraph 48 of the Pittsburgh Summit Communique, 25 September 2009.

45 Paul Blustein, The Misadventures of the Most Favored Nations; Clashing Egos, Inflated Ambitions and the Great Shambles of the World Trading System (New York: Public Affairs, 2010) 8. Ultimately, Blustein comes to the conclusion that the question is not how to save the Doha Round, but, in the words of Ernesto Zadillo, 'how can the WTO be saved from the Doha Round?' (at page 281). The answer, says Blustein, seems to belie his characterization of the system: 'The most important goal is to ensure the survival of the rules-based trading system. It is unwise to devote a lot of energy to opening markets more than they already are; after eight rounds, global trade is already reasonably free. The focus should be on keeping protectionism, and quasi-protectionism, from becoming long-lasting features of the international economy, so that globalized trade can help the world recover and prosper anew' (at page 286).

46 Ibid, at 280 . 
round. Progress has been made but, in the absence of any supranational authority, it relies on the very gradual consensus building. ${ }^{47}$

In contrast, other finance experts see the WTO's success in dispute settlement and enforcement as the model for the international financial system. ${ }^{48}$

Those who measure the success of the trading system entirely against its success in achieving the next generation of free trade objectives fail to appreciate the value of preserving the gains of over three quarters of a century of negotiations; what the European Union would call the acquis, the body of rules to which all members must adhere. Indeed, it would be more accurate to talk about the benefits of a well-regulated system of trade rather than free trade because that is what we have. People who condemn the WTO solely for its failure to deliver on the Doha Round agenda make the same mistake as those who measured the success of the financial regulatory regime against its ability to facilitate financial innovation by opening markets to ever more exotic (and sometimes toxic) financial instruments. There is great merit in pursuing a Doha Round deal to the extent that it can truly contribute to global growth and recovery, but failure in this regard does not make the existing rules outmoded or irrelevant. On the contrary, for all those who earn their livelihood from trade, the WTO operates to reduce risk and thereby cost, eliminate uncertainty and provide a critical source of stability for the global economy. Moreover, that is why the WTO has become a magnet for global regulatory issues from climate change to currency manipulation.

These views provide an appropriate set of cautions as we look with a critical eye at what aspects of the trading system contributed most to its ability to withstand the stress test of the Great Contraction. Even more importantly, they form an integral part of the perception of this institution and, as we have learned from the financial crisis, perceptions can play a large role in influencing the market. George Akerlof and Robert Shiller have criticized traditional economics for its failure to understand the importance of animal spirits in the functioning of the economy, namely 'confidence, fairness, corruption and antisocial behavior, money illusion and stories' ${ }^{49}$ They explain that economic theory has failed to appreciate that economic crises 'are mainly caused by changing thought patterns.... It was caused precisely by our changing confidence, temptations, envy, resentment, and illusions and especially by changing stories about the nature of the economy'. ${ }^{50}$

${ }^{47}$ Viral V. Acharya, Paul Wachtel and Ingo Walter, 'International Alignment of Financial Sector Regulation', in Viral V. Acharya and Matthew Richardson (eds), Restoring Financial Stability: How to Repair a Failed System (New Jersey: John Wiley \& Sons, 2009) 365-76, at 372.

${ }^{48}$ See Evenett, above n 9, at 218.

${ }^{49}$ George A. Akerlof and Robert Shiller, Animal Spirits: How Human Psychology Drives the Economy and Why it Matters for Global Capitalism (Princeton and Oxford: Princeton University Press, 2009) 5.

${ }^{50}$ Ibid, at 4. 
'The public, and the regulators who were supposed to act on their behalf, had failed to understand a fact of life that is totally obvious to everyone who has played a serious team sport: there have to be rules and there has to be a referee who enforces them - and a good and conscientious referee at that. ${ }^{, 51}$

There are a number of characteristics of the GATT/WTO system that appear relevant in explaining why the system performed so well as a systemic regulator.

\section{Rule-oriented system}

The very essence of the WTO is what John Jackson has christened the 'rule-oriented approach' that focuses on the importance of predictability and stability for those who must function within the international trading system and for whom the size and nature of the 'risk premium' inherent in international transactions can be the critical determinant for their long-term decisions regarding investment. Ultimately, this predictability and stability when institutionalized creates the base of a pyramid upon which many private decisions are grounded and the larger and more secure that base, the higher the pyramid can be built. The confidence that this set of rules can withstand even exogenous shock like a financial crisis must be seen as the ultimate validation for the role that rules can play. ${ }^{52}$

\section{Alignment of incentives with the public good}

Rules alone are not enough to protect a system from systemic risk. We know that systemic risk is created when the actions of an individual may be rational and advance the individual's interest but if everyone acts in the same way the system may collapse. The rules must serve an overall objective with incentives for behavior that is best for the overall public interest. Kenneth Dam talks about the theory of the second best, that in a world of second bests, it is not always clear whether the elimination of a particular barrier will lead to greater efficiency. ${ }^{53}$ The GATT confronted the problem of how to reconcile differing views of the function of international trade. While the USA saw trade as critically important to the promotion of international efficiency, other countries, especially in the developing world, saw economic development as their top priority. What the GATT and WTO have been able

${ }^{51}$ Ibid, at xiii.

52 See Jackson, above n 27 , at 88 :

The phrase 'rule orientation' is used here to contrast with phrases such as 'rule of law', and 'rule-based system'. Rule orientation implies a less rigid adherence to 'rule' and connotes some fluidity in rule approaches which seems to accord with reality (especially since it accommodates some bargaining or negotiations). Phrases that emphasize too strongly the strict application of rules sometimes scare policy makers, although in reality they may amount to the same thing.

${ }^{53}$ Kenneth W. Dam, The GATT: Law and International Economic Organization (Chicago: The University of Chicago Press, 1970) 6. 
to do through successive rounds of negotiations is focus the attention of Members on the common good that comes from the accumulation of individual concessions. In this respect, the GATT/WTO has followed Dam's advice of 1970 that it 'attempt not only to resolve this conflict in values but to aid governments in clarifying the common interest of all members of the international trading community. Neither rules nor mere pragmatic improvisations can do that'. ${ }^{54}$

The question is how negotiations can orient countries with essentially mercantilist attitudes toward trade to serve the public good. Economic theory (known as the market access or terms of trade theory) now tells us that the principle of reciprocity which, although not required as a principle of negotiations by any provision of the GATT/WTO agreements, provides a critical incentive, particularly for large countries, to lower their trade barriers. ${ }^{55}$ Reciprocity is operationalized in the GATT Article XXIII:1 provision which provides members recourse in the event that they feel the benefits to which they are entitled are being 'nullified or impaired' whether by a violation of the agreement, any measure, or any other situation.

Whether there is a counterpart in finance to the set of rules and an internal dynamic that ties those rules to the public good is a prime question for public policy and is at the heart of the national legislative efforts for financial regulatory reform. ${ }^{56}$ One way to replicate the benefit of the nullification or impairment provision of the GATT/WTO would be to adopt, as a first principle in an international financial agreement, the concept of systemic failure and the concept that countries must regulate in such a way as to protect against global systemic failure. Thus, as an analogy to GATT Article XXIII, a global financial agreement would ensure that any member has recourse if it faces the risk of a systemic crisis as a result of the actions of another member, including a violation of any provision of the agreement, any other measure (including the failure to regulate), or any other situation.

\section{Dispute settlement and self-enforcement}

While there are many examples of international agreements with elaborate sets of rules, the WTO is unique in the scope and importance of its juridical system for interpretation of the rules and the concentration of peer pressure on a violator. The success of the dispute settlement mechanism as a means of managing trade disputes-large and small, and between developed and

${ }^{54}$ Ibid, at 7.

55 See Chad P. Bown, Self-Enforcing Trade: Developing Countries and WTO Dispute Settlement (Washington, DC: Brookings Institution Press, 2009) 16: 'There is nothing in the GATT texts that requires countries to reciprocally negotiate market access liberalization.'

${ }^{56}$ Financial reform legislation has been enacted in the United States which creates a Financial Services Oversight Council to go with its European counterpart, the European Systemic Risk Board. The focus of these regulatory bodies could well be the source of international initiatives to strengthen the international regulatory system as advocated in this paper. Dodd-Frank Consumer Protection and Financial Reform Act, Public Law 111-203, 21 July 2010. 
developing countries-is the crown jewel of the global economic regulatory order. Moreover, the rate of adherence to the WTO rules, both in general and in response to disputes brought, is a singular achievement for the system and is at the heart of its success as a systemic regulator in the face of the recent crisis.

The counterpart to the market access theory is the commitment theory that holds 'without the threat that. . foreign market access will be taken away if one country deviates from the agreement by imposing new trade barriers, market access openings could not be sustained through renegotiations either. ${ }^{57}$ Critical to the WTO model is that it does not involve an imperial international bureaucracy that imposes its will on the Member but rather 'the GATT/WTO is a set of self-enforcing agreements: member countries enforce trading partners' commitments embodied in the agreements by challenging each other's missteps through forced dispute settlement' ${ }^{58}$

\section{Regulatory capture and the political economy underlying effective global} regulation

Rules and alignment with the public good still do not ensure that the system will not be captured by those interests it seeks to regulate. In the case of the WTO, 'the rule system shelters national governments from the power of protectionist groups within individualized economies....The WTO has been likened to a mast to which - like Odysseus - governments can tie themselves to escape the siren-like calls of domestic interest groups and even, to some extent, of their voters'. ${ }^{59}$

5. Comprehensive coverage - the domain of the regulatory system is coextensive with the domain of the problem

The WTO rules are comprehensive in their coverage geographically as well as functionally. WTO obligations cover 153 Members 'comprising 93\% of world trade, and $87 \%$ of world population' ${ }^{60}$ In geographical and demographic terms, the major breakthrough came with the admission of China on 11 December 2001, validating the WTO's claim to be the 'world' trade organization. ${ }^{61}$ From a functional perspective, the WTO has a comprehensive approach to the regulation of international trade for it covers explicitly any measure that a country may use to regulate trade. Moreover, the WTO incorporated the GATT concept that a 'nullification or impairment' of the benefits of the agreement could come from 'the application by any Member

${ }^{57}$ Bown, above n 55, at 19 .

${ }^{58}$ Ibid, at 20.

${ }^{59}$ Horst Siebert, Rules for the Global Economy (Princeton: Princeton University Press, 2009) 76.

${ }^{60}$ See Jackson, above n 27, at 135 .

${ }^{61}$ Russia remains the last major hold-out and has recently announced that it will proceed with its own accession without linking its accession to that of its customs union partners-Belarus and Kazakhstan: see Russia to pursue separate WTO bid, April 26, 2010, http://www.wto. ru/en/news.asp?msg_id=26135 (visited 3 August 2010). 
of any measure, whether or not it conflicts with the provisions' of one of the constituent agreements or 'the existence of any other situation'. ${ }^{62}$ While no case of a non-violation nullification complaint has ever been successful and the clause has been characterized as 'of little practical significance', ${ }^{63}$ the provision takes on significance from a systemic perspective. For one, it precludes the possibility that parties might engineer a measure outside the scope of the agreement. Furthermore, it acts as a kind of magnet, drawing issues into the trade regulatory system that could emerge as the perception regarding the scope of international trade versus domestic policy changes ${ }^{64}$ along with the responsibility of trading nations to their partners in maintaining the integrity of the regulatory system.

\section{Transparency}

A critical element in the success of the GATT/WTO is the use of transparency as a regulatory device. Members are required to disclose the measures that they use to regulate trade and to include them in their Schedules of Concessions. ${ }^{65}$ Transparency plays two roles: it enables the Members to enforce one another's commitments by directly monitoring them and it forces Members to confront their own domestic constituencies with the reality and substance of measures that end up imposing a cost on their domestic economies. This transparency has worked over time to help forge the constituencies of interest that then lobby for the elimination of barriers to trade. ${ }^{66}$

Transparency as a device for financial regulation is a subject of considerable interest and complexity. Ken Rogoff cites transparency as one of the most important roles for international institutions but points out how difficult it can be to obtain accurate data on things like government debt and the composition of the Federal Reserve's assets. ${ }^{67} \mathrm{~A}$ culture of nontransparency seems to be a characteristic of the financial system, even though some

${ }^{62}$ Article XXIII:1(c) of the GATT 1994 and Article 26.2 of the Understanding on Rules and Procedures Governing the Settlement of Disputes.

${ }^{63}$ Peter Van Den Bossche, The Law and Policy of the World Trade Organization (New York: Cambridge University Press, 2008) 185.

${ }^{64}$ See C. Fred Bergsten, 'Managing the World Economy of the Future' in Peter Kenan (ed), Managing the World Economy: Fifty Years after Bretton Woods (Washington, DC: Institute for International Economics, 1994) 3-57, at 342: 'International economic negotiations now routinely address, and even sometimes alter, policies traditionally viewed as "purely domestic.",

${ }^{65}$ GATT Article II.

${ }^{66}$ See generally Bown, above $\mathrm{n} 55$ for the view that these constituencies did not develop in those developing countries that were given special and differential treatment and were not required to offer concessions in negotiations.

${ }^{67}$ See Carmen M. Reinhart and Kenneth S. Rogoff, This Time is Different: Eight Centuries of Financial Folly (Princeton and Oxford: Princeton University Press, 2009) 282: 'One has only to look at how opaque the United States government's books have become during the 2007 financial crisis to see how helpful an outside standard would be.... The task of enforcing transparency is easier said than done, for governments have many incentives to obfuscate their books.' 
analysts see this as even more effective than supervision and limits on leverage. ${ }^{68}$ Complicating the picture is the view that the more transparency, the more information is homogeneous which leads to markets reacting in the same way to information and thereby creating systemic risk. ${ }^{69}$

\section{Governance}

The consensus-based system of the WTO has been its most widely criticized dimension because of the obstacles it creates to the rule-making process. Yet, when looked at from a systemic point of view, the legitimacy of the WTO is grounded in this rule. China's adherence to the WTO is in part attributable to the legitimacy it gets from a principle of governance that contrasts to that of the IMF (and other international financial institutions) where voting power is allocated according to an economic formula that is static and resistant to revision, even in the face of changes in underlying economic alignments.

Ultimately, the sustainability of the trading system in the face of the real world stress of the Great Contraction must stand as the highlight of an extraordinary history. The story is far from over and enormous pressures on the system continue to be felt, but the structure held with the ongoing support of the Members. The so-called bicycle theory of the international trading system - which holds that without forward progress on trade liberalization, the system would lose its balance and fall over-has not been proven, at least in this recent crisis.

\section{CONCLUSION-THE QUEST FOR COHERENCE}

At the heart of this article is the idea that we need to pull the covers back and face the real challenges of regulation in our globalized world. Coherence can only be achieved by adopting a mindset, tools and analytical frameworks that enable us to look at the 'nuts and bolts' as well as at the way the entire system fits together. If all economics is global and all politics are local, then regulators work in that space where the two come together and can only be reconciled by making economics work for the community and ensuring that all political decisions are taken with an eye to their impact on the global community. What Jack Welch called a culture of 'boundarylessness ${ }^{70}$ is a necessary component of our regulatory culture, by which he meant that one

${ }^{68}$ See Barth et al., above n 11, at 312 .

69 See discussion of the importance of heterogeneity in markets and the problem created by equal information in Alexander et al., above n 5, at 261: 'But the attainment of equal information is bought at a cost-increased homogeneity and, hence, potentially reduced liquidity.'

${ }^{70}$ Jack Welch was the CEO of General Electric from 1981 to 2001. See Jack Welch, Straight From The Gut (Warner Books Inc., 2001). 
must respect the limits of one's own responsibility while being mindful of the impact and need to share across functions and organizations.

We have just lived through the most dramatic economic event of our generation and, while there is an air of normalcy to this recovery, we have yet to digest the real consequences and implications of this crisis for the global economy.

From the perspective of the past 80 years and through the prism of global regulation, it appears that the worlds of trade and finance have evolved in two dramatically different directions, with the world of finance characterized by an almost pathological antipathy to regulation while the trade world has developed through trial and error an extensive set of rules, adjudication and dispute settlement mechanisms and sanctions which together have ensured a high degree of enforcement and compliance. This difference has consequences and helps to explain the relative performance of the two systems in the course of the real world crisis.

So the question can legitimately be posed: does the trading system deserve a voice in efforts to ensure global stability? The reason for an affirmative response is twofold. First, the trading system has experience in designing and operating a successful systemic regulatory system that for all the claimed differences between regulating trade and finance has in fact confronted many of the same problems facing the world of finance, such as rule making, sovereignty, political economy, reconciling conflicting values, economic theories and governance to name but a few. Second, the trading system has a huge stake in the outcome of the financial reform process for the same reason that the financial system was created, namely to facilitate payment and finance of international trade transactions. In fact, it is fair to say that trade started out as the weak sister in the Bretton Woods system and now it is the tent-pole holding up a system in which the other two pillars are showing signs of extreme distress.

This reality leads to the question: why does the WTO not have a seat on the Financial Stability Board? Have we not learned that taking a fragmented approach to the regulation of the global economy is flawed? Is it not possible that the next systemic risk could come from the inability of the trading system to hold up the global economy while the world of finance works its way through the political obstacles to reform? And is there not some chance that a representative of arguably the most successful systemic regulator in the history of humankind might have something to offer to an attempt to fundamentally restructure the regulatory system of finance?

This analysis raises a host of other questions that deserve further examination. Do we need a greater convergence in the global regulatory regimes governing trade and finance? Do we need a new paradigm for understanding global regulation that gets beyond the polarized debate over regulation versus deregulation? What are the implications for how we view the Doha Round 
and other efforts at the further liberalization of trade? How do we look at the interplay of rules and governance? What stake does the private sector have in the outcome of this debate and is the private sector playing an effective role in proposing solutions to the underlying problem of how to harness the benefits of globalization while managing the risks that are inevitably a part of making it work? 